\title{
Adsorption of Some Alephatic Dicarboxylic Acids on Zinc Oxide: A kinetic and Thermodynamic Study
}

\author{
Saddam. M. Al-Mahmoud
}

Received 23/10/2018, Accepted 15/4/2019, Published 1/12/2019

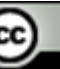

\begin{abstract}
:
The adsorption of Malonic acid, Succinic acid, Adipic acid, and Azelaic acid from their aqueous solutions on zinc oxide surface were investigated. The adsorption efficiency was investigated using various factors such as adsorbent amount, contact time, initial concentration, and temperature. Optimum conditions for acids removal from its aqueous solutions were found to be adsorbent dose $(0.2 \mathrm{~g})$, equilibrium contact time (40 minutes), initial acids concentration $(0.005 \mathrm{M})$. Variation of temperature as a function of adsorption efficiency showed that increasing the temperature would result in decreasing the adsorption ability. Kinetic modeling by applying the pseudo-second order model can provide a better fit of the data with a greater correlation coefficient, which indicates that the adsorption process follow the pseudo-second order kinetics. The negative values of Gibbs free energy and the enthalpy change confirm the spontaneous and exothermic nature of the adsorption process. A good ability of zinc oxide to remove aliphatic dicarboxylic acids from its aqueous solutions has been found, and the chain length of the acids has no significant effect on its adsorption.
\end{abstract}

Key words: Adsorption; Aliphatic Dicarboxylic acids; Zinc oxide.

\section{Introduction:}

Water contamination resulting from various artificial processes is a serious problem that requires great attention. Wastewater discharged from agricultural and industrial activities contain both organic and inorganic contaminants $(1,2)$. Usually, organic contaminants undergo oxidation reaction to produce carboxylic acids including dicarboxylic acids as final products (3). Carboxylic acids represent one of the most water-soluble organic material in the nature, which can cause a serious health problems to humans (4).

Adsorption is one of the most recommended methods that has been widely used to treat organic contaminated from water, using different adsorbent materials such as, Activated carbon, clay, chitin, zeolite, metal oxides (5-7). Adsorption is a process that can be defined as the accumulation of a substance (adsorbate) onto the surface of a solid or liquid (adsorbent). It can be classified into two types depending on the attraction forces; Chemical adsorption due to the exchange of electrons, and physical adsorption resulted from physical forces such as Vander Waals forces and polarity (5).

Department of Chemistry, College of Education for Women, Tikrit University, Tikrit, Iraq.

E-mail: $\underline{\text { s_almahmoud@tu.edu.iq }}$
Many researchers reported the use of activated carbon for removal of organic contaminated from water (8-15). Zinc oxide due to its significant physical and chemical properties is considered as a multifunctional material, which can be widely used in different applications (16-18). This study aims to investigate the ability of zinc oxide for the removal of aliphatic dicarboxylic acids from aqueous solution.

\section{Materials and Methods:}

All chemicals were used as received. Malonic acid (BDH), Succinic acid (Fluka), Adipic acid (Fluka), Azelaic acid (BDH). $\mathrm{ZnO}$ used in the study from May \& Baker LTD England (99 \% purity, average particle size $\sim 5 \mu \mathrm{m}$ ).

In this study, many experiments were conducted in order to investigate the effect of the contact time, adsorbent amount, initial concentration, and temperature. For each experiment, a series of aliphatic dicarboxylic acid solution were prepared by placing a $20 \mathrm{ml}$ of known concentration and $\mathrm{ZnO}$ amount in $100 \mathrm{ml}$ conical flask.

Each solution was shaken in a controlled shaking water bath using a constant speed of 120 rpm for about 40 min. under thermostatic condition in order to reach the adsorption equilibrium. The 
solution then filtered, and the supernatant titrated with $0.01 \mathrm{M}$ Sodium hydroxide solution. The amount of aliphatic dicarboxylic acid adsorbed on the surface of $\mathrm{ZnO}$ then calculated from the concentration difference.

The adsorption efficiencies are calculated using the equation below:

$$
\% \text { Adsorption }=\left(C_{0}-C_{e}\right) / C_{0} \times 100
$$

Where, $\mathrm{C}_{0}$ is the initial concentration $(\mathrm{mg} / \mathrm{L})$ of the acid, $\mathrm{C}_{\mathrm{e}}$ is the concentration $(\mathrm{mg} / \mathrm{L})$ of the acid at equilibrium.

The amounts of acid adsorbed at time $\mathrm{t}$ calculated using the following equation $(3,8)$ :

$$
q_{t}=\left(C_{0}-C_{e}\right) \mathrm{V} / \mathrm{m}
$$

Where, $q_{t}$ is the quantity of acid adsorbed per gram of adsorbent $(\mathrm{mg} / \mathrm{g}), \mathrm{V}$ is the volume of the acid solution (lit.), and $\mathrm{m}$ is the mass of the adsorbent (g).

Moreover, the adsorption kinetic study was performed using two different models, the lagergren's pseudo-first order model (Eq. 3), and pseudo-second order model (Eq. 4):

$$
\begin{gathered}
\log \left(q_{e}-q_{t}\right)=\log q_{e}-\left(k_{1} / 2.303\right) t \\
t / q_{t}=\left(1 / k_{2} q_{e}^{2}\right)+\left(1 / q_{e}\right) t
\end{gathered}
$$

Where $q_{e}$ is the adsorption capacity $(\mathrm{mg} / \mathrm{g})$ at equilibrium, $q_{t}$ is the adsorption capacity $(\mathrm{mg} / \mathrm{g})$ at time t, $k_{1}$ is the pseudo-first order rate constant $\left(\mathrm{min}^{-1}\right), k_{2}$ is the pseudo-second order rate constant (g. $\left.\mathrm{mg}^{-1} \cdot \mathrm{min}^{-1}\right)$.

Finally, the thermodynamic study for the adsorption of the acids on $\mathrm{ZnO}$ was evaluated using the following equations:

$$
\begin{gathered}
\Delta G^{\circ}=-R T \ln K \\
\Delta G^{\circ}=\Delta H^{\circ}-T \Delta S^{\circ} \\
\ln K=\left(\Delta S^{\circ} / R\right)-\left(\Delta H^{\circ} / R T\right)
\end{gathered}
$$

Where, $\mathrm{R}$ is the gas constant $(8.314 \mathrm{~J} / \mathrm{mol} \mathrm{K})$, $\mathrm{T}$ is the absolute temperature $(\mathrm{K}), \Delta \mathrm{H}^{\circ}$ is the enthalpy change $(\mathrm{J} / \mathrm{mol}), \Delta \mathrm{S}^{\circ}$ is the entropy change $(\mathrm{J} / \mathrm{mol}$ $\mathrm{K}), \Delta \mathrm{G}^{\circ}$ is the free energy change $(\mathrm{J} / \mathrm{mol}), \mathrm{K}$ is the distribution coefficient of adsorption process, and can calculated using the following equation:

$$
K=\left(C_{0}-C_{e}\right) / C_{e}
$$

\section{Results and discussion:}

Four aliphatic dicarboxylic acids with different chain length were investigated. The chemical structure of these acids is given in Fig. 1.

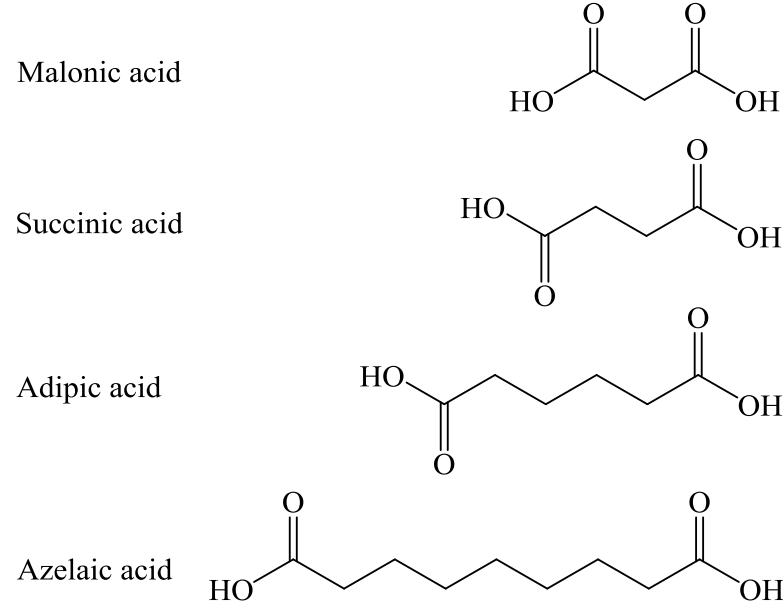

Figure 1. The chemical structure of Malonic acid, Succinic acid, Adipic acid, and Azelaic acid.

The variation of the contact time as a function of adsorption efficiency was investigated. Figure 2 displays the effect of the contact time on the removal of Malonic acid, Succinic acid, Adipic acid, and Azelaic acid by Zinc oxide. There can be seen a fast removal of the aliphatic carboxylic acids by $\mathrm{ZnO}$ in the first few minutes. This indicates a high affinity between the acids and the $\mathrm{ZnO}$ surface, which corresponds to the existence of a large number of unoccupied adsorption sites on the adsorbent. After that, a gradual increase in the adsorption process is observed as the time going on, and the uptake level becomes slower due to the decrease in the accessible adsorption sites. After 40 minutes, the adsorption process becomes constant, and no further adsorption can take place. This may occur because of the great decrease of the accessible adsorption sites, and the residual sites are hard to occupy due to the resistance between the adsorbate particles on the surface of the adsorbent and the incoming adsorbate particles (3). This indicates that equilibrium point can be reached in about 40 minutes for all considered acids.

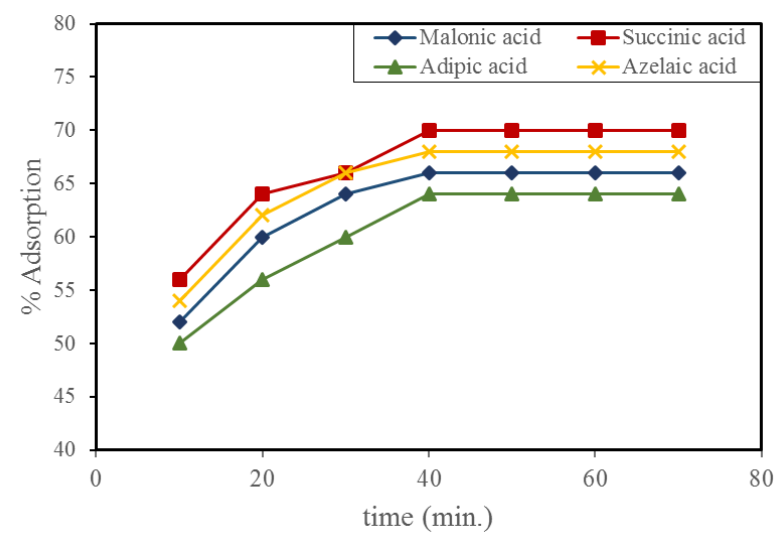

Figure 2. Effect of contact time on the adsorption of Malonic acid, Succinic acid, Adipic acid, and Azelaic acid on $\mathrm{ZnO}$. 
The variation of adsorbent dosage was also investigated. Figure 3 represents the effect of $\mathrm{ZnO}$ amount on the adsorption of Malonic acid, Succinic acid, Adipic acid, and Azelaic acid. It is more likely that using a small amount of the adsorbent can remove a small amount of the adsorbate, which might be related to the adsorption sites number. Thus, it can clearly be seen that the initial values of the acids removal are very small, and as the amount of $\mathrm{ZnO}$ increased, the removal of the acids was also increased to reach its maximum value when using $0.2 \mathrm{gm}$ of the adsorbent. It is possible that increasing the adsorbent amount can provide more accessible adsorption sites that can adsorb more adsorbate particles and thus increase the adsorption percentage(19). After that, the adsorption process becomes constant, because the residual sites are hard to be occupied, thus no further adsorption between the adsorbate particles and adsorbent surface can take place, which is considered to be approaching the equilibrium point.

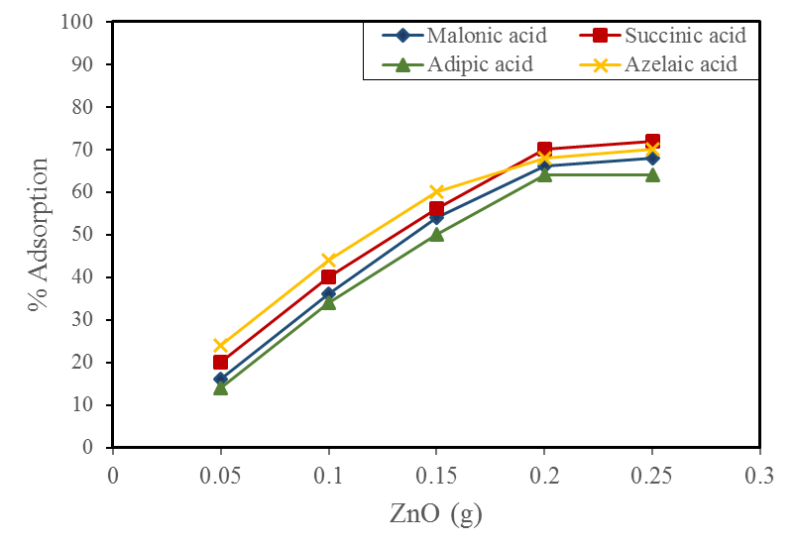

Figure 3. Effect of the $\mathrm{ZnO}$ amount on the adsorption of Malonic acid, Succinic acid, Adipic acid, and Azelaic acid.

The effect of the initial concentration on the adsorption efficiency was investigated using different acids concentrations ranging between 0.001 and $0.0125 \mathrm{M}$, and keeping the other parameters constant. Figure 4 shows the effect of the initial concentration on the adsorption of Malonic acid, Succinic acid, Adipic acid and Azelaic acid on $\mathrm{ZnO}$ surface. There can be clearly observed good adsorption efficiency with low acids concentration, and the uptake level continued almost constant with increasing the concentration until reaching $0.005 \mathrm{M}$. After that, as the acids concentration increases, the removal efficiency decreases. This is probably due to the existence of a large number of free adsorption sites on the adsorbent at the beginning of the adsorption process in comparison with the adsorbate particles number (20). In addition, as the acids concentration increases, the ratio of the adsorbate particles that will occupy the adsorption sites decreases. Thus, the percentage of the adsorbate removal will decrease and lowering the adsorption efficiency. This indicates that $0.005 \mathrm{M}$ can be considered as the optimal concentration.

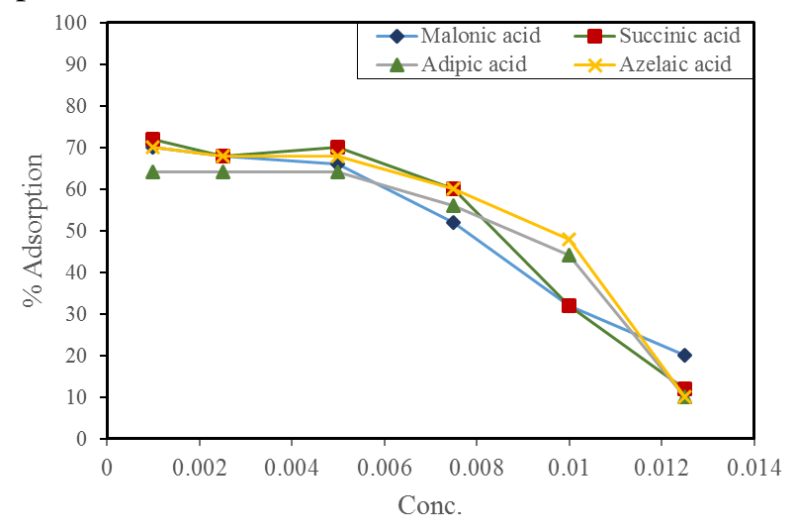

Figure 4. Effect of the concentration on the adsorption of Malonic acid, Succinic acid, Adipic acid, and Azelaic acid on $\mathrm{ZnO}$.

The effect of temperature on the removal of the aliphatic dicarboxylic acids by $\mathrm{ZnO}$ was tested using different temperatures in the range of 20-60 ${ }^{\circ} \mathrm{C}$. Figure 5 displays the effect of the temperature on the adsorption of Malonic acid, Succinic acid, Adipic acid, and Azelaic acid on $\mathrm{ZnO}$. There is clearly good adsorption efficiency at low temperature with initial values of about $\% 70$. As the temperature increased, the level of the acid removal decreased for all considered acids. This suggests that adsorption process of the studied acids is an exothermic process, and rising the temperature would result in reducing the adsorption ability (21).

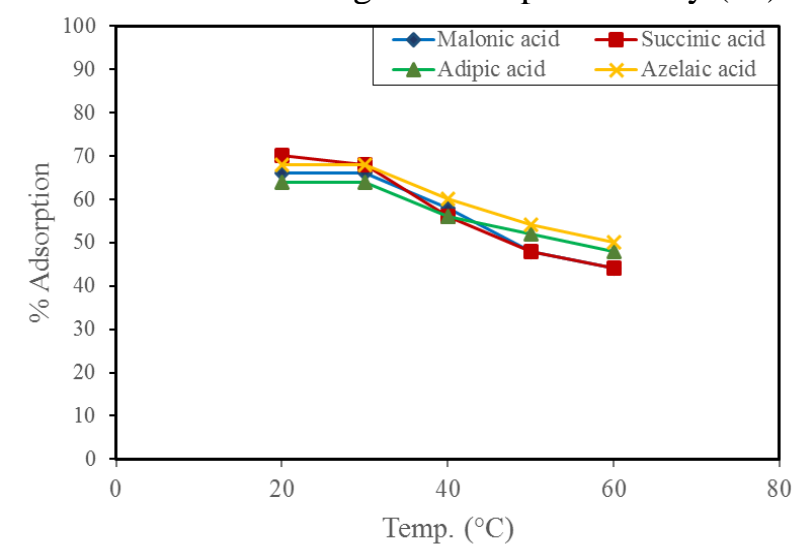

Figure 5. Effect of the temperature on the adsorption of Malonic acid, Succinic acid, Adipic acid, and Azelaic acid on ZnO.

\section{Kinetic studies:}

The kinetic studies were carried out to understand the adsorption mechanism during the transfer of acids particles from bulk solution to the adsorbent surface. Two different models were applied in order to investigate the kinetic of acids adsorption on $\mathrm{ZnO}$; the Lagergren's pseudo-first 
order rate equation (Eq.3) and pseudo-second order rate equation (Eq.4)

The rate of acids adsorption using pseudo first order model was performed by plotting $\log \left(\mathrm{q}_{\mathrm{e}}-\mathrm{q}_{\mathrm{t}}\right)$ versus time (Fig. 6), and the values of $\mathrm{k}_{1}$ and calculated $\mathrm{q}_{\mathrm{e}}$ are obtained from the slopes and intercepts of the straight lines, respectively. Similarly, for the pseudo second order model, the values of $\mathrm{k}_{2}$ and calculated $\mathrm{q}_{\mathrm{e}}$ are determined from the intercepts and the slopes of the straight lines resulted from the plot of $t / \mathrm{q}_{\mathrm{t}}$ versus time, respectively Fig. 7.

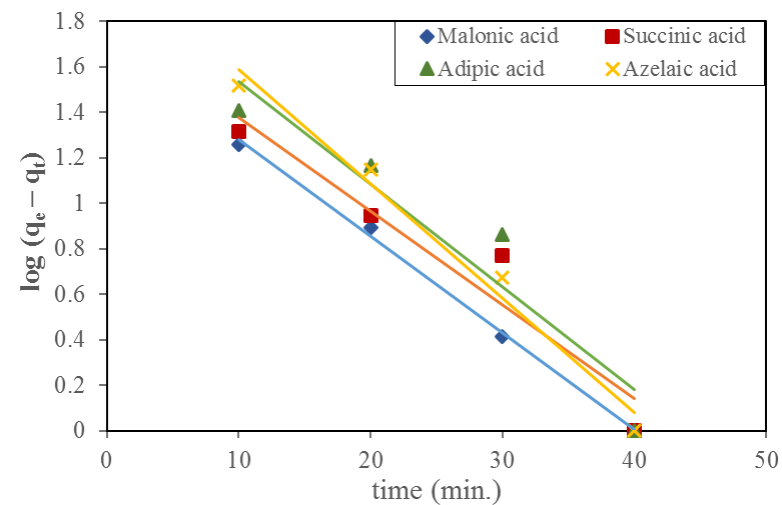

Figure 6. Pseudo-first order kinetic plot for acids adsorption on $\mathrm{ZnO}$ surface.

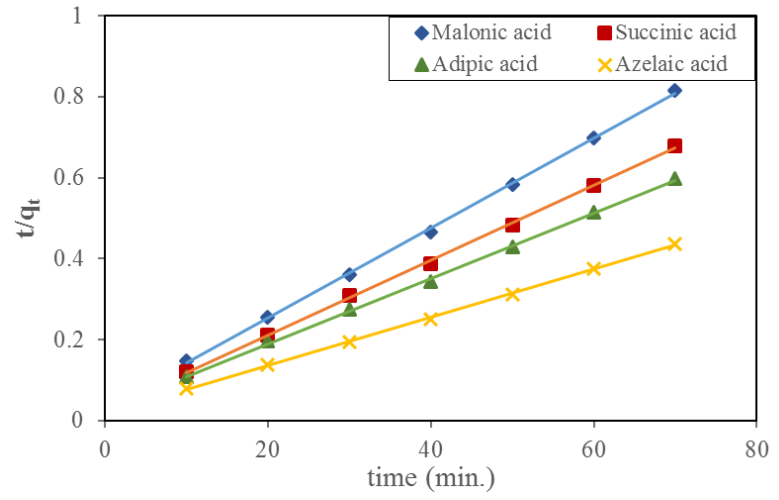

Figure 7. Pseudo-second order kinetic plot for acids adsorption on $\mathrm{ZnO}$ surface.

The kinetic parameters for the adsorption of the acids onto $\mathrm{ZnO}$ surface obtained from the fitting of kinetic models on the adsorption data are presented in Table 1. The comparison between the experimental and the calculated values of the adsorption capacities $\left(\mathrm{q}_{\mathrm{e}}\right)$, clarify that the pseudosecond order kinetic model provided a better fit of the data.

Table 1: Kinetic parameters for the adsorption of acids onto $\mathrm{ZnO}$ surface.

\begin{tabular}{|c|c|c|c|c|}
\hline \multicolumn{5}{|c|}{ Pseudo-first order model } \\
\hline Adsorbate & $\mathbf{k}_{1}\left(\min ^{-1}\right)$ & $\overline{\mathbf{R}^{2}}$ & $q_{\mathrm{e}}$ cal. $(\mathrm{mg} / \mathrm{g})$ & $q_{e} \exp .(\mathrm{mg} / g)$ \\
\hline Malonic acid & 0.098108 & 0.9978 & 50.82765 & 85.8 \\
\hline Succinic acid & 0.094884 & 0.9223 & 61.43276 & 103.25 \\
\hline Adipic acid & 0.104096 & 0.9038 & 97.63376 & 116.8 \\
\hline Azelaic acid & 0.115841 & 0.9817 & 123.7656 & 159.9955 \\
\hline \multicolumn{5}{|c|}{ Pseudo-second order model } \\
\hline Adsorbate & $\mathbf{k}_{2}\left(\mathrm{~g} \cdot \mathrm{mg}^{-1} \cdot \mathrm{min}^{-1}\right)$ & $\mathbf{R}^{2}$ & $q_{\mathrm{e}}$ cal. $(\mathrm{mg} / \mathrm{g})$ & $\mathrm{q}_{\mathrm{e}} \exp .(\mathrm{mg} / \mathrm{g})$ \\
\hline Malonic acid & 0.003975 & 0.9994 & 90.09009 & 85.8 \\
\hline Succinic acid & 0.00317 & 0.9994 & 108.6957 & 103.25 \\
\hline Adipic acid & 0.002255 & 0.9991 & 123.4568 & 116.8 \\
\hline Azelaic acid & 0.002236 & 0.9994 & 166.6667 & 159.9955 \\
\hline
\end{tabular}

Moreover, high correlation coefficients were obtained from fitting the tow kinetic models, however, the correlation coefficient of pseudosecond order kinetic model are greater than that for pseudo-first order kinetic model (Table 1). These results confirm that the adsorption process follows the pseudo second order kinetics.

\section{Thermodynamic studies:}

Obtaining the thermodynamic parameters can provide a good clarification for the mechanism of the adsorption process. The distribution coefficient of adsorption process $(\mathrm{K})$ was calculated at different temperatures using Eq. 8. The value of Gibbs free energy change $\Delta \mathrm{G}^{\circ}$ was determined using Eq. 5. While, $\Delta \mathrm{H}^{\circ}$ and $\Delta \mathrm{S}^{\circ}$ were obtained according to Van't Hoff equation (Eq. 7), from the slope and intercept of the straight line resulted from the plot of $\ln \mathrm{K}$ versus 1/T, respectively Fig. 8. 


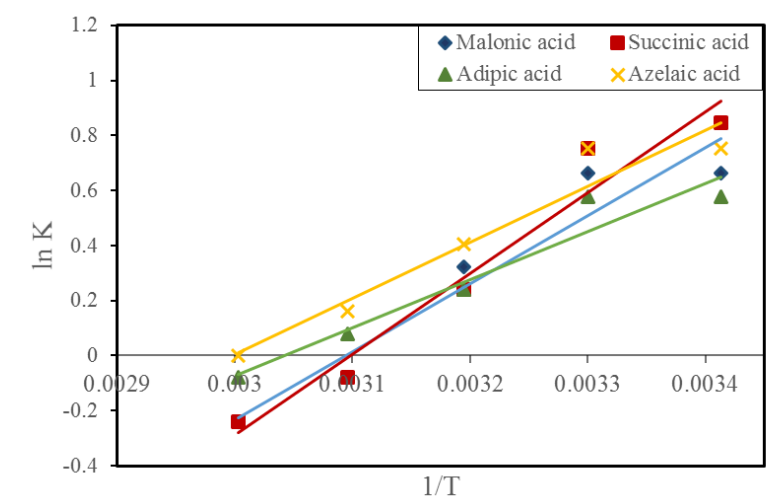

Figure 8. Van't Hoff plot for acids adsorption on ZnO surface.

The thermodynamic parameters $\left(\Delta \mathrm{G}^{\circ}, \Delta \mathrm{H}^{\circ}\right.$ and $\Delta \mathrm{S}^{\circ}$ ) for the adsorption of acids onto $\mathrm{ZnO}$ surface are listed in Table 2. These parameters were evaluated at various temperatures $\left(20-60{ }^{\circ} \mathrm{C}\right)$ with initial concentration of $0.005 \mathrm{M}, 0.2 \mathrm{~g}$ of adsorbent, and 40 minutes contact time. The negative values of $\Delta \mathrm{H}^{\circ}$ for all acids considered in this study indicate that the adsorption of acids onto $\mathrm{ZnO}$ surface is exothermic. This is compatible with the early conclusion, which reveals that the adsorption efficiency decreased with the increase in temperature Fig. 5. In addition, the negative values of $\Delta \mathrm{G}^{\circ}$ indicates that the adsorption process have a spontaneous nature. Furthermore, the negative values of $\Delta \mathrm{S}^{\circ}$ indicate that the randomness increased at the solid/solution interface through the adsorption process.

Table 2: Thermodynamic parameters for the adsorption of acids onto $\mathrm{ZnO}$ surface at various temperatures.

\begin{tabular}{lccc}
\hline Adsorbate & $\begin{array}{c}\Delta \mathbf{H}^{\circ} \\
\left(\boldsymbol{J} . \mathbf{m o l}^{-1}\right)\end{array}$ & $\begin{array}{c}\Delta \mathbf{S}^{\circ} \\
\left(\boldsymbol{J} . \mathbf{m o l}^{-1} . \boldsymbol{K}^{\mathbf{I}}\right)\end{array}$ & $\begin{array}{c}\Delta \mathbf{G}^{\circ} \\
\left(\boldsymbol{J} . \mathbf{m o l}^{-1}\right)\end{array}$ \\
\hline $\begin{array}{l}\text { Malonic } \\
\text { acid }\end{array}$ & -20581.3 & 63.68108 & -1615.79 \\
$\begin{array}{l}\text { Succinic } \\
\text { acid }\end{array}$ & -24411.6 & 75.62248 & -2134.46 \\
$\begin{array}{l}\text { Adipic acid } \\
\text { Azelaic }\end{array}$ & -14597.7 & 44.41921 & -1497.26 \\
acid & -16968 & 50.86671 & -2024.2 \\
\hline
\end{tabular}

\section{Conclusion:}

The adsorption characteristic for the adsorption of aliphatic dicarboxylic acids on zinc oxide has been examined. The optimal values for the removal of aliphatic dicarboxylic acids by zinc oxide are adsorbent dosage $0.2 \mathrm{gm}$, contact time 40 min., and initial concentration $0.005 \mathrm{M}$. Kinetic modeling shows that the adsorption process follows the pseudo-second order kinetics with a better correlation coefficient. The thermodynamic parameters emphasizes that the adsorption process is spontaneous and exothermic in nature. These results indicate that zinc oxide can be utilized successfully for the removal of dicarboxylic acids from aquios solutions, and the chain length of the aliphatic dicarboxylic acid has no important effect on its adsorption.

\section{Conflicts of Interest: None.}

\section{References:}

1. Elias M, Hassain MA, Samdani MA, Amin MK, Suhag MH, Safwan JA, et al. Kinetic and Thermodynamic Studies of Adsorption of Benzoic Acid on to Activated Charcoal. Int Conf Clim Chang Impact Adapt. 2013;671-8.

2. Babu SA, Raja S, Sibi S, Neeraja P. Electrochemical oxidation of textile polluted water and its reuse. Jr Ind Pollut Control. 2012;28(1):73-82.

3. Foya H, Mdoe JE, Mkayula LL. Adsorption of Maleic and Oxalic Acids on Activated Carbons Prepared from Tamarind Seeds. Int $\mathbf{J}$ Eng Res Technol. 2014;3(4):1035-42.

4. Blower PG, Shamay E, Kringle L, Ota ST, Richmond GL. Surface behavior of malonic acid adsorption at the air/water interface. J Phys Chem A. 2013;117(12):2529-42.

5. Kausar A, Iqbal M, Javed A, Aftab K, Nazli Z, Nawaz H, et al. Dyes adsorption using clay and modi fi ed clay: A review. J Mol Liq [Internet]. 2018;256:395-407. Available from: https://doi.org/10.1016/j.molliq.2018.02.034

6. Saeed WN. Removal of Azo Dye Reactive Black 5 By Adsorption onto $\mathrm{ZnO}$ and $\mathrm{CaO}$. J Kerbala Univ. 2013;11(4):321-30.

7. Yu C, Han X. Adsorbent Material Used In Water Treatment-A Review. 2nd Int Work Mater Eng Comput Sci. 2015;(Iwmecs):290-3.

8. Pakhre V, Srivastava VC. Adsorption of benzoic acid and salicylic acid onto granular activated carbon. Int Conf Chem Civ Environ Eng. 2012;261-5.

9. Anisuzzaman SM, Joseph CG, Taufiq-Yap YH, Krishnaiah D, Tay V V. Modification of commercial activated carbon for the removal of 2,4dichlorophenol from simulated wastewater. J King Saud Univ - Sci [Internet]. 2015;27:318-30. Available from: http://dx.doi.org/10.1016/j.jksus.2015.01.002

10. Omri A, Wali A, Benzina M. Adsorption of bentazon on activated carbon prepared from Lawsonia inermis wood: Equilibrium, kinetic and thermodynamic studies. Arab J Chem [Internet]. 2016;9:S1729-39. Available from: http://dx.doi.org/10.1016/j.arabjc.2012.04.047

11. Rattanapan S, Srikram J, Kongsune P. Adsorption of Methyl Orange on Coffee grounds Activated Carbon. Energy Procedia [Internet]. 2017;138:949-54. Available

from: https://doi.org/10.1016/j.egypro.2017.10.064

12. Aljeboree AM, Alshirifi AN, Alkaim AF. Kinetics and equilibrium study for the adsorption of textile dyes on coconut shell activated carbon. Arab J Chem [Internet]. 2017;10:S3381-93. Available from: 
http://dx.doi.org/10.1016/j.arabjc.2014.01.020

13. Pathania D, Sharma S, Singh P. Removal of methylene blue by adsorption onto activated carbon developed from Ficus carica bast. Arab J Chem [Internet]. 2017;10:S1445-51. Available from: http://dx.doi.org/10.1016/j.arabjc.2013.04.021

14. Wang H, Xie R, Zhang J, Zhao J. Preparation and characterization of distillers' grain based activated carbon as low cost methylene blue adsorbent: Mass transfer and equilibrium modeling. Adv Powder Technol [Internet]. 2018;29:27-35. Available from: https://doi.org/10.1016/j.apt.2017.09.027

15. Khan EA, Shahjahan, Khan TA. Adsorption of methyl red on activated carbon derived from custard apple (Annona squamosa) fruit shell: Equilibrium isotherm and kinetic studies. J Mol Liq [Internet]. 2018;249:1195-211. Available from: https://doi.org/10.1016/j.molliq.2017.11.125

16. Kolodziejczak-Radzimska A, Jesionowski T. Zinc oxide-from synthesis to application: A review. Materials (Basel). 2014;7(4):2833-81.

17. Agarwal H, Venkat Kumar S, Rajeshkumar S. A review on green synthesis of zinc oxide nanoparticles
- An eco-friendly approach. Resour Technol. 2017;3(4):406-13.

18. Vidya Lekshmi KP, Yesodharan S, Yesodharan EP. $\mathrm{MnO} 2$ and $\mathrm{MnO} 2 / \mathrm{TiO} 2$ mediated, persulphate enhanced photocatalysis for the removal of indigo carmine dye pollutant from water. Eur Chem Bull [Internet]. 2017;6(5):177-91. Available from: http://www.eurchembull.com/index.php/ECB/article/ view/1970

19. Salleh MAM, Mahmoud DK, Karim WAWA, Idris A. Cationic and anionic dye adsorption by agricultural solid wastes: A comprehensive review. Desalination [Internet]. 2011;280:1-13. Available from: http://dx.doi.org/10.1016/j.desal.2011.07.019

20. Mouni L, Belkhiri L, Bollinger J-C, Bouzaza A, Assadi A, Tirri A, et al. Removal of Methylene Blue from aqueous solutions by adsorption on Kaolin: Kinetic and equilibrium studies. Appl Clay Sci. 2018;153:38-45.

21. Al-Hyali EA, Al-Niemi KI, Al-Dubunee SA. Kinetic and Thermodynamic Study of the Adsorption of some Organic Acids by $\mathrm{MnO}$ 2. Tikrit J Pure Sci. 2012;17(2):105-11.

\section{امتزاز بعض الحوامض الاليفاتية ثنائية الكاربوكسيل على أوكسيد الزتك: دراسة حركية وثرموداينميكية \\ صدام محمد المحمود}

قسم الكيمياء، كلية التربية للبنات، جامعة تكريت، تكريت، العراق

الهدف من اجراء هذا البحث هو لدراسة ميكانيكية امتزاز حامض المالونيك، حامض السكسنيك، حامض الاديبيك، وحامض

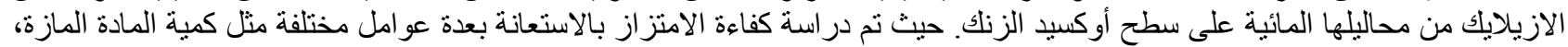

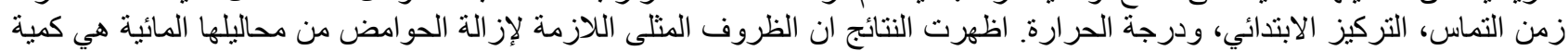

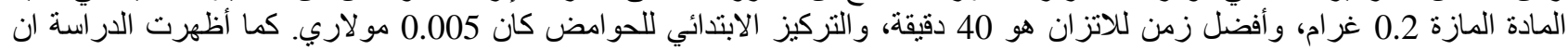

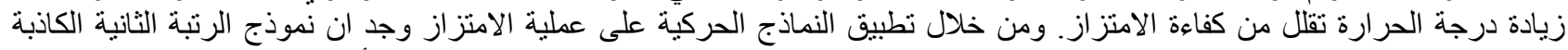

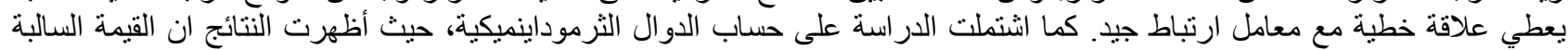

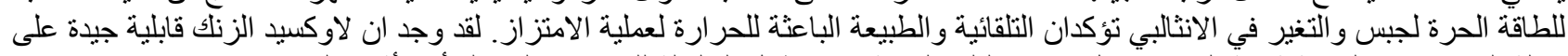

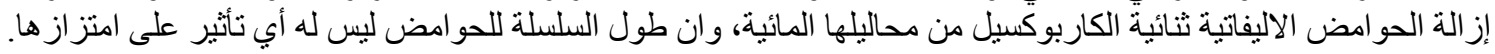

$$
\text { الكلمات المفتاحية: الامتزاز، الحو امض الاليفاتية ثنائية الكاربوكسيل، أوكسيد الزنك }
$$

